\title{
REKONSEPTUALISASI AKIBAT HUKUM PENGANGKATAN ANAK MENURUT KAJIAN KOMPILASI HUKUM ISLAM
}

\author{
Abidin Abidin, Abdullah Kelib \\ Magister Ilmu Hukum Universitas Semarang
}

\begin{abstract}
ABSTRAK
Tujuan dari penelitian ini adalah untuk mengetahui akibat hukum pengangkatan anak menurut kompilasi hukum islam. Secara legal bahwa mengangkat anak dikuatkan berdasarkan keputusan Pengadilan dan mempunyai akibat hukum yang luas antara lain menyangkut perwalian dan pewarisan. Metode pendekatan yang digunakan dalam penelitian ini adalah pendekatan yuridis sosiologis. Berdasarkan hasil penelitian yang dilakukan penulis bahwa rekonseptualisasi pengangkatan anak yaitu pengalihan tanggung jawab pemeliharaan anak, pemberian nafkah dan pendidikan dari orang tua kandung kepada orang tua angkat berdasarkan putusan pengadilan. Akibat hukum pengangkatan anak menurut Hukum Islam anak angkat tidak berstatus sama dengan anak kandung, hubungan dengan orang tua kandung tidak terputus, kekuasaan orang tua beralih tetapi tidak menjadi wali nikah anak angkat, mewaris dengan jalan wasiat wajibah. Dari rekonseptualisasi akibat hukum pengangkatan anak berdasarkan Peraturan Perundang-undangan dan Peraturan Pemerintah tentang pengangkatan anak terebut masih tersebar sehingga konsep pengangkatan anak masih bervariasi. Maka diperlukanadanya undang-undang nasional tentang pengangkatan anak sehingga adanya kesamaan dalam konsep dan akibat hukum pengangkatan anak.
\end{abstract}

\section{Kata kunci: Konsep; akibat hukum; pengangkatan anak}




\title{
RECISCUALIZATION OF LEGAL REMEDIES OF CHILDREN BY STUDY OF ISLAMIC COMPILATION STUDY
}

\author{
Abidin Abidin, Abdullah Kelib \\ Master of Law, University of Semarang
}

\begin{abstract}
The purpose of this study was to determine the legal consequences of adoption according to Islamic law compilation .Legally, the adoption of the child is upheld by the Court's decision and has extensive legal consequences, including trust and inheritance. The approach method used in this research is a sociological juridical approach. As a result of the law of adoption according to Islamic law the adopted child does not have the same status as the biological child, the relationship with the biological parents is not interrupted, the power of the parent switches but not the marriage of the adopted child, inheritance by mandatory will. From the reconceptualization of legal consequences of adoption based on the Laws and Regulations on the appointment of the child is still spread so that the concept of adoption varies. It is therefore necessary to have a national law on adoption so that there are similarities in the concepts and consequences of the adoption law
\end{abstract}

Keywords: Concepts; legal consequences; adoption 


\section{A. PENDAHULUAN}

Pengangkatan anak tersebut merupakan alternatif untuk menyelamatkan sebuah perkawinan atau untuk mencapai kebahagiaan dalam rumah tangga, karena salah satu tujuan dari perkawinan yang dilakukan adalah untuk memperoleh keturunan yaitu anak. Begitu pentingnya hal keturunan (anak) ini, sehingga bisa menimbulkan berbagai peristiwa hukum jika tiada keturunan (anak) diantaranya terjadinya perceraian, poligami dan pengangkatan anak merupakan beberapa peristiwa hukum yang terjadi karena alasan didalam perkawinan tidak memperoleh keturunan, walaupun bukan satu-satunya sebagai alasan.

Secara umum pengangkatan anak menurut hukum adalah pengalihan anak terhadap orang tua angkat dari orang tua kandung secara keseluruhan dan dilakukan menurut adat setempat agar sah. Jadi orang tua kandung sudah lepas tangan terhadap anak itu, dan tanggung jawab beralih kepada orang yang mengangkatnya.

Menurut hukum Islam pada prinsipnya mengakui dan membenarkan pengangkatan anak dengan ketentuan tidak boleh membawa perubahan hukum di bidang nasab, wali mewali dan aris mewaris.

Definisi anak angkat dalam Kompilasi Hukum Islam jika diperbandingkan dengan definisi anak angkat dalam Undang-Undang Nomor 23 Tahun 2002 tentang Perlindungan Anak, memiliki kesamaan substansi. Pasal 1 angka 9 dinyatakan bahwa “ Anak Angkat adalah anak yang haknya dialihkan dari lingkungan kekuasaan keluarga orang tua, wali yang sah, atau orang lain yang bertanggung jawab atas perawatan, pendidikan, dan membesarkan anak tersebut, ke dalam lingkungan keluarga orang tua angkatnya berdasarkan putusan atau penetapan pengadilan".

Hal penting yang perlu digaris bawahi bahwa pengangkatan anak harus dilakukan dengan proses hukum dengan produk penetapan pengadilan. Jika hukum berfungsi sebagai penjaga ketertiban dan sebagai rekayasa sosial, maka pengangkatan anak yang harus dilakukan melalui penetapan pengadilan tersebut merupakan kemajuan ke arah penertiban praktik hukum pengangkatan anak yang hidup di tengahtengah masyarakat, agar peristiwa pengangkatan anak itu di kemudian hari memiliki kepastian hukum baik bagi anak angkat maupun bagi orang tua angkat. Praktik 
pengangkatan anak yang dilakukan melalui pengadilan tersebut, telah berkembang baik di lingkungan Pengadilan Negeri maupun dalam lingkungan Pengadilan Agama bagi mereka yang beragama Islam.

Dalam prakteknya pengangkatan anak menimbulkan masalah di lapangan dan hal tersebut nampak sebagaimana yang terjadi di Pengadilan Agama dengan adanya konflik atas pengangkatan anak diantaranya kepastian atas anak yang diangkat secara hukum tidak diberikan hak-hak yang jelas akibat dari putusan yang masih kabur dalam menegaskan sejauh mana hak dan kewajiban dari para pihak jika anak tersebut berganti orang tua lain.

\section{B. PERMASALAHAN}

1. Bagaimana rekonseptualisasi model pengangkatan anak sesuai dengan hukum Islam?

2. Bagaimana akibat hukum pengangkatana anak dalam kajian KHI (Kompilasi Hukum Islam)?

\section{METODE PENELITIAN}

Metode ini menggunakan yuridis normatif yaitu usaha penemuan hukum (in concrete\} yang sesuai untuk diterapkan dalam menyelesaikan suatu masalah hukum tertentu. Dalam usaha tersebut digunakan data seperti perundang-undangan, keputusan-keputusan pengadilan, teori-teori hukum dan pendapat para sarjana terkemuka.

Penelitian ini menggunakan spesifikasi penelitian yang bersifat deskriptif analitis yaitu memaparkan, menggambarkan atau mengungkapkan Peraturan Perundang-Undangan yang berlaku dikaitkan dengan teori-teori hukum positif yang berlaku dan dalam praktek pelaksanaan hukum yang menyangkut permasalahan di atas.

Sumber jenis data-data yang dikumpulkan adalah data-data sekunder dari hukum positif, yang meliputi bahan-bahan hukum baik bahan hukum primer,yakni hasil peneliti ilmiyah dari kalangan hukum yang dikeluarkan oleh Pemerintah seperti Undang-Undang, Kompilasi Hukum Islam, dan bahan hukum sekunder, seperti 
penjelasan dari karya para peneliti hukum dan bahan hukum tersier seperti Kamuskamus membantu menerjemahkan berbagai istilah hukum.

Teknik pengumpulan data menggunakasn Data Sekunder, yakni mengumpulkan dengan cara studi Kepustakaan ( library research ).

\section{PEMBAHASAN}

\section{Pengertian Anak Angkat dan macam-macamnya}

a) Anak Angkat

Pasal 1 butir 9 Undang-Undang Nomor 23 Tahun 2002 jo. Pasal 1 butir 1 Peraturan Pemerintah Nomor 54 Tahun 2007 mengatakan bahwa yang dimaksud dengan : "Anak angkat adalah anak yang haknya dialihkan dari lingkungan kekuasaan keluarga orang tua, wali yang sah, atau orang lain yang bertanggung jawab atas perawatan, pendidikan, dan membesarkan anak tersebut ke dalam lingkungan keluarga orang tua angkatnya berdasarkan keputusan atau penetapan pengadilan".

Sedangkan menurut Pasal 171 huruf h KHI yaitu :

"Anak angkat adalah anak yang dalam hal pemeliharaan untuk hidupnya seharihari, biaya pendidikan dan sebagainya, beralih tanggung jawabnya dari orangtua asal kepada orangtua angkatnya berdasarkan putusan pengadilan”.

b) Anak Tiri

Adalah anak kepada isteri atau suami seseorang daripada perkawinan yang terdahulu.

c) Anak Susuan

Adalah anak yang disusui dengan cara masuknya air susu seorang wanita kepada anak kecil dengan syarat-syarat tertentu.

d) Laqith

Adalah anak yang dipungut di jalanan, sama dengan anak yatim, bahwa anak seperti ini lebih patut di namakan Ibnu Sabil, yang dalam Islam dianjurkan untuk memeliharanya.

e) Anak Asuh 
Anak asuh erat kaitannya dengan program wajib belajar yang dicanangkan Presiden RI pada tanggal 2 Mei 1984 bertepatan dengan Hari Pendidikan Nasional. Hubungan antara orang tua asuh dengan anak asuh sebatas berkaitan dengan bantuan biaya pendidikan agar anak asuh dapat mengikuti pendidikan pada lembaga pendidikan tingkat dasar sampai selesai. Oleh sebab itu, lembaga anak asuh berbeda dengan lembaga anak angkat.

f) Anak Piara

Menurut Hukum adat lembaga anak piara, yaitu seseorang menitipkan seorang anak kepada orang lain untuk dipelihara. Lembaga ini berbeda dengan lembaga pengangkatan anak, karena orang tua yang dititipi tersebut hanya melakukan tugas sebagai pemelihara. Demikian pula akibat hukumnya berbeda dengan pengangkatan anak.

g) Anak Pungut

Ada lagi yang membedakan antara anak pungut dengan anak angkat. Kedudukan anak angkat telah bernilai bahkan seperti mengambil kedudukan anak kandung, sedangkan anak pungut tidak mendapat kedudukan istimewa tetapi hanya mendapat pemeliharaan dari orang yang memungutnya. Pada anak angkat terdapat cinta, sedangkan pada anak pungut hanya terdapat belas kasihan. Kata "dipungut" menunjukkan makna mengambil sesuatu yang tidak atau kurang berarti, sedangkan "diangkat" bermakna meninggikan dari keadaan semula.

\section{Hubungan Hukum Antara Orang Tua dan Anak}

Di samping Undang-UndangNomor 1 Tahun 1974, Kompilai Hukum Islam pun mengatur mengenai kedudukan anak dalam Pasal 98 sampai Pasal 106. Kedudukan anak dalam Kompilasi Hukum Islam yaitu sebagai berikut:

1) Anak yang sah adalah (a) anak yang dilahirkan dalam atau akibat perkawinan yang sah, (b) hasil pembuahan suami istri yang sah diluar rahim dan dilahirkan oleh istri tersebut ( Pasal 99 ).

2) Anak yang dilahirkan diluar perkawinan hanya mempunyai hubungan nasab dengan ibunya dan keluarga ibunya ( Pasal 100 ). 
3) Suami yang mengingkari sahnya anak sedang istri tidak menyangkalnya dapat meneguhkan pengingkarannya dengan lisan dan mengajukan ke Pengadilan Agama dalam jangka waktu 180 hari sesudah lahirnya atau 360 hari sesudah putusnya perkawinan atau setelah suami mengetahui bahwa istrinya melahirkan anak dan berada ditempat memungkinkan dia mengajukan perkaranya ke Pengadilan Agama ( Pasal 101-102 ).

\section{a. Hak dan Kewajiban Anak}

Ada lima macam hak anak terhadap orang tuanya, yaitu :

1. hak nasab,

2. hak radla,

3. hak hadhanah,

4. hak walayah dan

5. hak nafkah.

Kewajiban-kewajiban anak pada orang tua menurut hukum Islam yaitu:

a. Taat dan berbakti kepada kedua orang tuanya.

b. Berkata lemah lembut kepada orang tua.

c. Memelihara orang tua sewaktu telah lanjut usia.

d. wajib menghormati orang tua dan mentaati hal yang baik.

\section{b. Pengangkatan Anak}

Pengangkatan anak atau adopsi berasal dari kata Adoptie dalam bahasa Belanda atau adoption dalam bahasa Inggris. Adoption artinya pengangkatan, pemungutan, adopsi, dan untuk sebutan pengangkatan anak disebut adoption of a child. Dalam bahasa arab disebut "tabanny" diartikan dengan mengambil anak angkat. Sedangkan dalam Kamus Munjid diartikan “ittikhadzahu”, yaitu menjadikannya sebagai anak.

Menurut Ensiklopedi Umum yang dikutip oleh Muderis Zaeni dalam bukunya menyebutkan bahwa : "Adopsi adalah suatu cara untuk mengadakan hubungan antara orang tua dan anak yang diatur dalam pengaturan perundang-undangan.

Dalam sejarah Islam, sudah sejak zaman Jahiliyah orang Arab telah mengenal dan melakukan pengangkatan anak. Pada waktu itu Nabi Muhammad S.A.W. mengangkat 
anak seorang laki-laki bernama Zaid bin Haritsah. Tindakan Nabi Muhammad S.A.W. ini mendapat teguran dari Allah melalui wahyu Illahi sebagaimana tertera dalam AlQur'an Surat Al-Azhab ayat 4, 5 dan 40, yang diturunkan untuk memperbaiki kesalahan Nabi Muhammad S.A.W. dalam mengangkat anak yang disesuaikannya dengan adat dan kebiasaan yang berlaku dalam kehidupan bangsa Arab waktu itu.

Menurut hukum Islam pengangkatan anak hanya dapat dibenarkan apabila :

a. Tidak memutuskan hubungan darah antara anak yang diangkat dengan orang tua biologis dan keluarga;

b. Anak angkat tidak berkedudukan sebagai ahli waris dari orang tua angkat, melainkan tetap sebagai ahli waris dari orang tua kandungnya, demikian juga orang tua angkat tidak berkedudukan sebagai ahli waris dari anak angkatnya;

c. Anak angkat tidak boleh mempergunakan nama orang tua angkatnya secara langsung, kecuali sekedar sebagai tanda pengenal / alamat;

d. Orang tua angkat tidak dapat bertindak sebagai wali dalam perkawinan terhadap anak angkatnya.

Dari ketentuan tersebut di atas bahwa prinsip pengangkatan anak menurut hukum Islam adalah bersifat pengasuhan anak dengan tujuan agar seorang anak tidak sampai terlantar atau menderita dalam pertumbuhan dan perkembangannya.

Berdasarkan prinsip hukum Islam tidak melarang memberikan berbagai bentuk bantuan atau jaminan penghidupan oleh orang tua angkat terhadap anak angkatnya, berupa:

1) Pemberian hibah kepada anak angkat untuk bekal hidupnya dikemudian hari;

2) Pemberian wasiat kepada anak angkat dengan ketentuan tidak lebih dari $1 / 3$ sepertiga ) harta kekayaan orang tua angkat yang kelak akan diwariskan kepada ahli warisnya yang berhak.

Pengangkatan anak menurut hukum Islam, tidak memberi status kepada anak angkat sebagai "anak kandung” orang tua angkat. Dan prinsip-prinsip pengangkatan anak menurut hukum Islam bertujuan mencegah agar seorang anak tidak sampai 
terlantar dalam hidupnya dan bersifat pengarahan yang dapat disertai dengan pemberian bantuan penghidupan untuk kesejahteraan anak.

\section{Alasan dan Tujuan Pengangkatan Anak}

\subsection{Alasan Pengangkatan Anak}

1) Dilihat dari sisi adoptant, karena ada:

1. Keinginan mempunyai keturunan atau anak;

2. Keinginan untuk mendapat teman bagi dirinya sendiri atau anaknya;

3. Kemauan untuk menyalurkan rasa belas kasihan terhadap anak orang lain yang membutuhkan;

4. Adanya ketentuan hukum yang memberi peluang untuk melakukan suatu pengangkatan anak;

5. Adanya pihak yang menganjurkan pelaksanaan pengangkatan anak untuk kepentingan pihak tertentu.

2) Dilihat dari sisi orang tua anak, karena:

1. Perasaan tidak mampu untuk membesarkan anaknya sendiri;

2. Kesempatan untuk meringankan beban sebagai orang tua karena ada pihak yang ingin mengangkat anaknya;

3. Imbalan-imbalan yang dijanjikan dalam hal penyerahan anak;

4. Saran-saran dan nasihat pihak keluarga atau orang lain;

5. Keinginan agar anaknya hidupnya lebih baik dari orang tua angkatnya;

6. Ingin agar anaknya terjamin materiil selanjutnya;

7. Masih mempunyai anak beberapa lagi;

8. Tidak mempunyai rasa tanggung jawab untuk membesarkan anaknya sendiri;

9. Keinginan melepaskan anaknya karena rasa malu sebagai akibat hubungan tidak sah;

10. Keinginan melepaskan anaknya karena rasa malu sebagai akibat hubungan tidak sah;

11. Keinginan melepaskan anaknya karena rasa malu mempunyai anak yang tidak sempurna fisiknya. 
e-ISSN : 2621-4105

\subsection{Tujuan Pengangkatan Anak}

Sesuai Undang-Undang RI Nomor 4 Tahun 1979 tentang Kesejahteraan Anak, adalah :

a. Anak berhak atas pemeliharaan dan perlindungan, baik semasa dalam kandungan maupun sesudah dilahirkan ( Pasal 2 ayat (3);

b. Anak berhak atas perlindungan terhadap lingkungan hidup yang dapat membahayakan atau menghambat pertumbuhan dan perkembangannya dengan wajar ( Pasal 2 ayat (4);

c. Pengangkatan anak menurut adat dan kebiasaan dilaksanakan dengan mengutamakan kepentingan kesejahteraan anak ( Pasal 12 ayat (1);

d. Pengangkatan anak untuk kepentingan kesejahteraan anak yang dilakukan di luar adat dan kebiasaan, dilaksanakan berdasarkan Peraturan Perundangundangan (Pasal 12 ayat (3).

\subsection{Dasar Hukum Pengangkatan Anak}

\subsubsection{Peraturan Perundang-Undangan:}

a) Undang-Undang Dasar 1945

b) Undang-Undang RI Nomor 1 Tahun 1974 Tentang Perkawinan.

c) Undang-Undang RI Nomor 4 Tahun 1979 Tentang KesejahteraanAnak.

d) Undang-Undang RI Nomor 39 Tahun 1999 Tentang Hak Asasi Manusia.

e) Undang-Undang RI Nomor 3 Tahun 2006 Tentang Perubahan Atas Undang Undang Nomor 7 Tahun 1989 Tentang Peradilan Agama.

f) Undang-Undang RI Nomor 12 Tahun 2006 Tentang Kewarganegaraan Republik Indonesia.

g) Undang-Undang RI Nomor 23 Tahun 2002 Tentang Perlindungan Anak.

h) Undang-Undang Nomor 23 Tahun 2006 Terntang Administrasi Kependudukan.

i) Peraturan Pemerintah No2 Tahun 2007 Tentang Tata Cara Memperoleh, Kehilangan, Pembatalan, dan Memperoleh kembali Kewarganegaraan Indonesia. ( Pasal 24)

j) Keputusan Mensos RI Nomor 4 Tahun 1989 Tentang Pengangkatan Anak. 
k) SEMA No 2 Tahun 1979 Tentang Pengangkatan Anak.

1) SEMA No6 Tahun 1983 Tentang Penyempurnaan Surat Edaran Nomor 2 Tahun 1979.

m)SEMA Nomor 4 Tahun 1989 Tentang Pengangkatan Anak.

\subsubsection{Al-Qur'an dan Al-Hadits.}

1) Al-Qur'an Surat Al-Isra'(17 : 23-24), diantaranya yaitu

Artinya : "Dan Tuhanmu telah memerintahkan supaya kamu jangan meyembah selain Dia dan hendaklah berbuat baik pada ibu bapakmu dengan sebaikbaiknya. Jika salah seorang diantara keduanya atau kedua-duanya samapi berumur lanjut dalam pemeliharaanmu, maka sekali-kali janganlah kamu mengatakan kepada keduanya perkatan "ah" dan janganlah kamu membentak mereka dan ucapkanlah kepada mereka perkataan yang mulia (sopan santun)"'( QS. Al-Isra': ayat 23 ). "Dan rendahkanlah dirimu terhadap mereka berdua denagn penuh kesayangan dan ucapkanlah: "Wahai Tuahnku, kasihanilah mereka keduanya, sebagai mana mereka berdua telah mendidik aku waktu kecil " (QS. Al-Isra': ayat 24 ).

2) Al-Qur'an Surat Al-Ahzab(33:4-5, 37 dan ayat 40), diantaranya :

Artinya :"Allah sekali-kali tidak menjadikan bagi seseorang dua buah hati dalam rongganya; dan Dia tidak menjadikan isterimu-isterimu yang kamu dzihar itu sebagai ibumu, dan Dia tidak menjadikan anak-anak angkatmu sebagai anak kandungmu (sendiri). Yang demikian itu hanyalah perkataanmu dimulutmu saja. Dan Allah mengatakan yang sebenarnya dan dia menunjukkan jalan (yang benar )'"(QS. Surat Al-Ahzab: Ayat 4). "Panggilah mereka ( anak-anak angkat itu ) denagn ( memakai) nama bapak-bapak mereka ; itulah yang adil pada sisi Allah, dan jika kamu tidak mengetahui bapak-bapak mereka, maka (panggilah mereka sebagai) saudara-saudaramu seagama dan amula-maulamu 1200). Dan tidak ada dosa atasmu terhadap apa yang kamu khilaf padanya, tetapi (yang ada dosanya) apa yang disengaja oleh hatimu.Dan adalah Allah Maha Pengampun lagi Maha Penyayang”( QS. Surat Al-Ahzab : 5 ). "Dan( ingatlah), ketika kamu berkata pada orang yang melimpahkan ni'mat kepadanya dan kamu (juga) telah memberi ni'mat kepadanya: "Tahanlah terus isterimu dan bertakwalah kepada Allah", sedang kamu menyembunyikan didalam hatimu apa yang Allah akan menyataknnya, dan kamu takut kepada manusia, sedang Allah-lah yang lebih berhak untuk kamu takuti. Maka tatkala Zaid telah mengakhiri keperluan terhadap isterinya(menceraikannya), Kami kawinkan kamu dengan dia supaya tidak ada keberatan bagi orang mu'min untuk (mengawini) isteri-isteri anak-anak angkat mereka, apabila anak-anak angkat itu telah menyelesaikan keperluannya dari pada isterinya. Dan adalah ketetapan Allah itu pasti terjadi."( QS. Surat Al-Ahzab : 37 ) "Muhammad itu sekali-kali bukanlah bapak dari seorang laki-laki di antara kamu, tetapi dia adalah Rasullulah dan 
penutup Nabi-Nabi. Dan adalah Allah Maha Mengetahui segala sesuatu”.( QS. Surat Al-Ahzab : 40 ).

3) Al-Qur'an Surat At-Taghaabun (64:15), yaitu :

Artinya :"Sesungguhnya hartamu dan ank-anakmu hanyalah cobaan (bagimu): dan di sisi Allah-lah pahala yang besar"

\subsubsection{Hadist Nabi SAW. diantaranya yaitu :}

2.3.3.1. HR. Riwayat Bukhari, seperti :

Artinya : "Barang siapa yang mendakwakan dirinya sebagai anak dari seseorang yang bukan ayahnya, maka kepadanya ditimpakan laknat Allah, para malaikat dan manusia seluruhnya. Kelak pada hari kiamat Allah tidak menerima darinya amalan-amalan dan kesaksiannya. (Al-Hadits)

2.3.3.2. Hadist Riwayat Muslim

Artinya : "Dari Abi Usman ia berkata : tatkala Zaud dipanggil bahwa ia telah dijadikan anak angkat, maka aku pergi menemui abu Bakhrah, lalu aku berkata kepadanya : Apa yang kalian lakukan ini ?. Bahwa aku telah mendengar Sa'ad bin Abi Waqqash berkata: Kedua telingaku telah mendengar dari Rasullulah SAW. Bersabda : "Barang siapa mengakui ( membangsakan )seorang ayah selain ayahnya dalam Islam, sedang ia tahu itu bukan ayahnya, maka haram baginya surga". (HR.Muslim)

2.3.3.3. Hadis Riwayat Bukhari Muslim, diantaranya :

a) Artinya :"Sesungguhnya Zaid bin Harisah adalah maula Rasullulah SAW.dan kami memanggilnya dengan Zaid bin Muhammad, sehingga turun ayat: Panggillah mereka dengan nama ayah (kandungnya), maka itulah yang lebih adil di sisi Allah, lalu Nabi bersabda ; " engkau adalah Zaid bin Harisah". (HR.Bukhori-Muslim)

b) Dari Abu Dzar r.a. bahwa ia mendengar Rasullulah SAW. Bersabda :

Artinya : "Tidak seorangpun yang mengakui (membangsakan diri) kepada orang yang bukan bapak yang sebenarnya, sedangkan ia mengetahui benar bahwa orang itu bukan ayahnya, melainkan ia telah kufur. Dan barang siapa yang telah melakukan hal itu, maka bukan dari golongan kami ( kalangan kaum muslimin) dan hendaklah dia menyiapkan sendiri tempatnya dalam api neraka. (HR.Bukhori-Muslim)

c) Dari Abdullah bin Abbas, Rasullulah SAW bersabda:

Artinya : "Janganlah berduaan salah seorang kamu dengan wanita kecuali bersama mahramnya". (HR.Bukhori-Muslim)

2.3.3.4. Hadits Nabi SAW, lainnya seperti :

Artinya : "Dari Saad bin Abi Waqqas ; Aku menderita sakit kemudian Nabi SAW. Mengunjungi dan aku tanyakan: "Wahai Rasullulah SAW. Berdoalah Tuan Kepada Allah semoga Dia tidak menolakku ".Beliau bersabda: "semoga Allah meninggikan (derajat)mu, dan manusia lain akan meperoleh manfaat dari kamu "Aku bertanya: "aku ingin mewasiatkan hartaku separuh, namun aku ada seorang anak perempuan". Beliau menjawab: "Separuh itu banyak "aku bertanya (lagi 
) :" sepertiga?". Beliau menjawab : "sepertiga, sepertiga, adalah banyak atau besar". Beliau bersabda : "orang-orang berwasiat sepertiga, dan yang demikian itu boleh bagi mereka”.(Al-Hadits)

3. Kompilasi Hukum Islam (KHI)

- Pasal 98 - 101, Pasal 106, Pasal 171 huruf h, dan Pasal 209

\section{A. Peradilan Agama dan Kedudukan Peradilan Agama}

Undang-Undang Nomor 7 Tahun 1989 Tentang Peradilan Agama yang diubah menjadi Undang-Undang Nomor 3 Tahun 2006 tentang Perubahan atas UndangUndang Nomor 7 Tahun 1989 Tentang Peradilan Agama.

"Peradilan Agama adalah salah satu pelaku kekuasaan kehakiman bagi rakyat pencari keadilan yang beragama Islam mengenai perkara tertentu sebagaimana dimaksud dalam Undang-Undang ini.“ (Pasal 2 UU No 3 Tahun 2006)

\section{A.1. Susunan Organisasi Peradilan Agama}

Susunan organisasi Peradilan Agama dijelaskan dalam Pasal 6 UndangUndang Nomor 3 Tahun 2006, adalah sebagai berikut :

"Pengadilan terdiri dari :

1. Pengadilan Agama, yang merupakan Pengadilan tingkat Pertama;

2. Pengadilan Tinggi Agama, yang merupakan Pengadilan tingkat Banding.”

Dalam Pasal 9 Undang-Undang Nomor 3 Tahun 2006 dijelaskan tentang susunan Pengadilan Agama terdiri dari Ketua, hakim anggota, panitera, sekretaris dan juru sita. Dan susunan Pengadilan Tinggi Agama terdiri dari pimpinan, anggota, penitera dan sekretaris. Sedangkan dalam Pasal 10 dijelaskan bahwa pimpinan Pengadilan Agama terdiri dari seorang ketua dan seorang wakil ketua. Begitu pula dengan pimpinan di Pengadilan Tinggi Agama. Namun hakim anggota Pengadilan Tinggi Agama adalah hakim tinggi.

\section{Kekuasaan dan Kewenangan Peradilan Agama Tentang Pengangkatan Anak}

Untuk menerapkan kewenangan absolut Pengadilan Agama dalam memberikan penetapan pengangkatan anak berdasarkan hukum Islam. Sesuai ketentuan Pasal 54 Undang-Undang RI Nomor 7 Tahun 1989 jo Undang-Undang RI 
Nomor 3 Tahun 2006, maka dalam hal ini hukum acara yang berlaku adalah hukum acara perdata yang berlaku pada pengadilan dalam lingkungan peradilan umum.

Kewenangan Pengadilan Agama itu juga diatur pada Pasal 49 Ayat (1) Undang-Undang Nomor 7 Tahun 1989 Tentang Pengadilan Agama yang menegaskan bahwa Pengadilan Agama bertugas dan berwenang memeriksa, memutus, dan menyelesaikan perkara-perkara di tingkat pertama antara orang-orang yang beragama Islam. Akidah Islam yang melekat dalam diri seseorang menjadi patokan kewenangan Pengadilan Agama Terhadap suatu perkara.

Lembaga pengangkatan anak sudah lazim dilakukan oleh masyarakat muslim Indonesia. Kehadiran Kompilasi Hukum Islam yang merupakan himpunan kaidah-kaidah Islam yang disusun secara sistematis dan lengkap mengakui eksistensi lembaga pengangkatan anak tersebut dengan mengaturnya dalam ketentuan Pasal 171 huruh h jo Pasal 209. Pasal-pasal tersebut memberikan batasan pengertian anak angkat dan akibat hukum terjadinya hubungan wasiat wajibah antara anak angkat dengan orang tua angkatnya. Kompilasi Hukum Islam ini menjadi sumber hukum Islam bagi masyarakat muslim Indonesia yang melakukan perbuatan hukum pengangkatan anak dan menjadi pedoman hukum materiil bagi Pegadilan Agama dalam mengadili perkara pengangkatan anak.

\section{Rekonseptualisasi Model Pengangkatan Anak sesuai dengan Hukum Islam}

Tabanni secara harfiah diartikan sebagai seseorang yang mengambil anak orang lain untuk diperlakukan seperti anak kandung sendiri. Hal ini itu dilakukan untuk memberi kasih sayang, nafkah pendidikan dan keperluan lainnya. Secara hukum anak itu bukanlah anaknya.

Adopsi dinilai sebagai perbuatan yang pantas dikerjakan oleh pasangan suami istri yang luas rezekinya, namun belum dikaruniai anak. Maka itu, sangat baik jika mengambil anak orang lain yang kurang mampu, agar mendapat kasih sayang ibubapak (karena yatim piatu), atau untuk mendidik dan memberikan kesempatan belajar kepadanya. 
Hanya saja, ketika mengangkat (adopsi) anak, jangan sampai si anak putus hubungan keturunan (nasab) dengan ayah dan ibu kandungnya. Sebab, hal ini bertentangan dengan syariat Islam. Jadi, Adopsi yang dilakukan berdasarkan Hukum Islam, tidak menjadikan anak yang diangkat mempunyai hubungan dengan orangtua angkat seperti hubungan yang terdapat dalam hubungan darah.

\section{A. Akibat Hukum Pengangkatan Anak dalam Kajian KHI (kompilasi Hukum Islam)}

\section{B.1. Nasab (hubungan darah)}

Anak angkat tidak memutus hubungan darah antara anak yang diangkat dengan orang tua biologisnya.

\section{B.2. Perwalian}

Dalam hal perwalian, sejak putusan diucapkan oleh pengadilan, maka orang tuaangkat menjadi wali dari anak angkat tersebut. Sejak saat itu pula, segala hak dankewajiban orang tua kandung beralih pada orang tua angkat. Kecuali bagi anak angkat perempuan beragama Islam, bila dia akan menikah maka yang bisa menjadi wali nikahnya hanyalah orangtua kandungnya atau saudara sedarahnya.

\section{B.3. Waris}

Khazanah hukum kita, baik hukum adat, hukum Islam maupun hukum nasional, memiliki ketentuan mengenai hak waris. Ketiganya memiliki kekuatan yang sama, artinya seseorang bisa memilih hukum mana yang akan dipakai untuk menentukan pewarisan bagi anak angkat.

Dengan demikian dalam Kompilasi Hukum Islam, pengangkatan anak tidak membawa akibat hukum dalam hal hubungan darah, hubungan wali-mewali dan hubungan waris mewaris dengan orangtua angkat. Ia tetap menjadi ahli waris dari orang tua kandungnya dan anak tersebut tetap memakai nama dari ayah kandungnya. Pada prinsipnya dalam hukum Islam, hal pokok dalam kewarisan adalah adanya hubungan darah atau arhaam.Namun anak angkat dapat mewaris dengan jalan wasiat wajibah sesuai denganketentuan Pasal 209 Kompilasi Hukum Islam bahwa seorang 
e-ISSN : 2621-4105

anak angkat berhak 1/3 (sepertiga) bagian dari Harta Peninggalan orangtua angkatnya sebagai suatu wasiat wajibah.

\section{E.PENUTUP}

Pengangkatan anak berdasarkan Kompilasi Hukum Islam (KHI) adalah pengangkatan anak yang bersumber pada Al-Qur'an dan sunnah serta hasil ijtihad yang berlaku di Indonesia yang diformulasikan dalam berbagai produk pemikiran hukum Islam, baik dalam bentuk fikih, fatwa, putusan pengadilan, maupun peraturan perundang-undangan. Akibat hukum pengangkatan anak menurut Kompilasi Hukum Islam yakni sesuai dengan syari'at Islam sebagai berikut : Pengangkatan Anak Tidak Mengakibatkan Perubahan Nasab, Pengangakatan Anak Tidak Mengakibatkan Akibat Hukum Saling Mewarisi, Anak angkat tidak boleh mempergunakan nama orang tua angkat secara langsung dan anak tetap memakai nama dari Bapak kandung, Orang tua angkat tidak dapat bertindak sebagai wali dalam perkawinan terhadap anak angkatnya. Pengangkatan anak yang bertentangan dengan ajaran Islam yaitu mengangkat anak dengan memberikan status yang sama dengan anak kandung. Sedangkan kalau yang dimaksud mengangkat anak dalam batas memelihara dalam rangka menolong sesama maka hukumnya diperbolehkan bahkan dianjurkan. 


\section{DAFTAR PUSTAKA}

\section{Buku}

Abdul Wahab Khallaf, 1978, Ushul Fiqh. Quwait : Dar al-Qalam

Ahmad Kamil dan M. Fauzan, 2008, Hukum Perlindungan dan Pengangkatan Anak di Indonesia, PT. Raja Grafindo Persada,Jakarta.

Andi Syamsu Alam dan M. Fauzan, 2008, Hukum Pengangkatan Anak Perspektif Islam, Kencana Prenada Media Group, Jakarta.

Amir Mu'allim dan Yusdani, 2001, Konfigurasi Pemikiran Hukum Islam, UII Press, Yogyakarta.

Ahmad Rofiq, 2001, Fiqh Mawaris Edisi Revisi, PT. Raja Grafindo Persada, Jakarta. Aziz Dahlan, 1996, Ensiklopedi Hukum Islam, PT. Ichtiar Baru Van Hoeve, Jakarta. At-Tufi, 1972 ,Syarah al-arba'in Nawawiyyah, Kuwait: Dar al-Qalam.

Bambang Waluyo, 1991, Penelitian Hukum Dalam Praktek, Sinar Grafika Jakarta.

Bushar Muhammad, 2006, Pokok-Pokok Hukum Adat, Pradnya Paramita, Jakarta.

Djaja S. Meliala, 1982, Pengangkatan Anak ( Adopsi) di Indonesia, Tarsito, Bandung.

Fuad Moch dan Fachruddin, 1991, Masalah Anak Dalam Hukum Islam, Pedoman Ilmu Jaya, Jakarta.

Husain Ansarian, 2000, Struktur Keluarga Islam, Intermasa, Jakarta.

Irma Setyowati Soemitro, 1990, Aspek Hukum Perlindungan Anak, Bumi Aksara, Jakarta.

\section{Undang - Undangan :}

Undang-Undang Dasar 1945 Hasil Amandemen, Sinar Grafika, Jakarta,2004.

Undang - Undang RI Nomor 1 Tahun 1974 Tentang Perkawinan, SinarGrafika, Jakarta, 2004.

Undang - Undang RI Nomor 4 Tahun 1979 Tentang Kesejahteraan Anak,Sinar Grafika, Jakarta, 2002.

Undang - Undang RI Nomor 39 Tahun 1999 Tentang Hak Asasi Manusia,Sinar Grafika, Jakarta, 2002.

Undang - Undang RI Nomor 23 Tahun 2002 Tentang Perlindungan Anak,Sinar Grafika, Jakarta, 2004.

Undang - Undang RI Nomor 4 Tahun 2004 Tentang KekuasaanKehakiman, Himpunan Peraturan Perundang - undangan RI, JilidI, CV. Citra Mandiri, Jakarta, 2004.

Undang - Undang RI Nomor 3 Tahun 2006 tentang Perubahan AtasUndang - Undang Nomor 7 Tahun 1989 Tentang PeradilanAgama, Sinar Grafika, Jakarta, 2006.

Undang - Undang RI Nomor 12 Tahun 2006 Tentang KewarganegaraanRI, Sinar Grafika, Jakarta, 2008.

Instruksi Presiden RI Nomor 1 tahun 1991 Tentang Kompilasi hukum Islam, Gema Insani Pers, Jakarta, 1994.

Surat Edaran Ketua Mahkamah Agung Republik Indonesia Nomor 2Tahun 1979 Tentang Pengangkatan Anak.

Surat Edaran Ketua Mahkamah Agung Republik Indonesia Nomor 6Tahun 1983 Tentang Penyempurnaan Surat Edaran Nomor 2Tahun 1979. 
Rekonseptualisasi Akibat Hukum Pengangkatan Anak Menurut Kajian Kompilasi Hukum Islam Abidin Abidin, Abdullah Kelib

e-ISSN : 2621-4105

Surat Edaran Ketua Mahkamah Agung Republik Indonesia Nomor 4Tahun 1989 Tentang Pengangkatan Anak. 